\title{
Report Source ICSR Terminology
}

National Cancer Institute

\section{Source}

National Cancer Institute. Report Source ICSR Terminology. NCI Thesaurus. Code C54587.

Terminology used in Individual Case Safety Reports to specify information on a report source, section G3 of FDA MedWatch Form. 